\title{
UJI AKTIVITAS ANTIBAKTERI DAN FITOKIMIA KULIT BAWANG MERAH (Allium cepa L.) HASIL EKSTRAKSI METODE Microwave Assisted Extraction (MAE)
}

\section{Microwave-Assisted Extraction Method (MAE) On Antibacterial Activity and Phytochemical Screening of Onion skin (Allium Cepa L.)}

\author{
Fitria Dewi Sulistiyono*, Trirakhma Sofihidayati dan Bina Lohitasari \\ Program Studi Farmasi, Fakultas MIPA Universitas Pakuan, Bogor \\ Jl. Pakuan, Tegallega, Bogor Timur
}

\begin{abstract}
ABSTRAK
Ekstrak kulit bawang merah mengandung flavonoid, polifenol, saponin, terpenoid dan alkaloid. Metode ekstraksi modern dengan memanfaatkan radiasi gelombang mikro yang disebut dengan MAE (Microwave Assisted Extraction) belum banyak dilakukan. Metode MAE terbukti lebih efektif karena pemanasan pelarut secara cepat dan efisien dibandingkan metode ekstraksi secara konvensional. Tujuan penelitan ini adalah mengetahui senyawa fitokimia dan aktivitas ekstrak kulit bawang merah dengan metode MAE pada Staphylococcus aureus. Deteksi senyawa fitokimia dilakukan dengan metode kualitatif, yaitu ada tidaknya senyawa flavonoid, saponin, alkaloid dan tanin. Aktivitas ekstrak kulit bawang merah terhadap S.aureus dilakukan dengan metode kertas cakram dengan melihat zona bening/hambat yang dihasilkan. Konsentrasi ekstrak yang digunakan adalah 5, 10, 15, 20 dan 25\% (b/v). Hasil penelitian menunjukkan bahwa ektrak kulit bawang merah mempunyai senyawa flavonoid, saponin dan tanin. Ekstrak kulit bawang merah dapat menghambat pertumbuhan S.aureus ditunjukkan dengan adanya zona bening dari kosentrasi 5, 10, 15, 20 dan 25\% (b/v) adalah 14; 15,5; 16; 19; 19,5 mm. Hasil tersebut menunjukan bahwa MAE lebih efektif daripada metode konvensional (maserasi) dalam menghambat $S$. aureus. Berdasarkan hasil aktivitas antibakteri, ekstrak kulit bawang merah dapat dimanfaatkan dalam dunia industri sebagai salah satu komponen produk pencegahan infeksi bakteri.
\end{abstract}

Kata kunci: fitokimia, kulit bawang merah, metode MAE, Staphylococcus aureus

\begin{abstract}
Onion skin extract containing flavonoid, catakin , saponin, terpenoid and alkaloid . Microwave Assisted Extraction (MAE) is modern method with microwave radiation. MAE have proven more effective because a solvent warming quickly and more efficient compared other methode (maseration). This study aims to explore the phytochemical activity presenced in onion skin extract. that was obtained by the Microwave Assited Extraction (MAE) method and to evaluate the antibacterial activity against Staphilococcus aureus. The phytochemical screening of onion skin extracted by using MAE revealed the presence of alkaloids, saponins, tannins and flavonoids. The antibacterial activity of onion skin extract was carried out against $S$. aureus by
\end{abstract}


measuring the diameter of bacterial growth inhibition zones through the diffusion method. The results of qualitative phytochemical screening tests on onion skin extract shows that the positive sample contains alkaloids, saponins, tannins and flavonoids. Range of onion skin extract concentration used in this research were $5,10,15,20$, and $25 \% \mathrm{w} / \mathrm{v}$. The inhibition zone of extract at concentration $5,10,15,20$, and $25 \% \mathrm{w} / \mathrm{v}$ were $14.00 ; 15.50 ; 16.00 ; 19.00$; and $19.50 \mathrm{~mm}$ respectively. Base on antibacterial result, onion skin extract can be used as one ingredient in the manufacture of antibacterial products.

\section{Keywords : MAE method, Onion skin, Phytochemical, Staphylococcus aureus}

\section{Penulis korespondensi:}

Fitria Dewi Sulistiyono

Program Studi Farmasi, Universitas Pakuan

Jl. Pakuan, Tegallega, Bogor Timur

Email: fitria.sulistiyono@unpak.ac.id

\section{PENDAHULUAN}

Di Indonesia banyak sekali tanaman yang sering dimanfaatkan oleh masyarakat sebagai bahan pangan ataupun sebagai obat, akan tetapi untuk limbah tanaman masih jarang. Salah satu contohnya adalah limbah kulit bawang merah yang banyak dihasilkan dari limbah rumah tangga. Penelitian sebelumnya telah diketahui bahwa ekstrak kulit bawang merah mengandung senyawa kimia yang berpotensi sebagai antioksidan yaitu flavonoid yang dapat mencegah berkembangnya radikal bebas di dalam tubuh sekaligus memperbaiki sel-sel tubuh yang rusak (Soebagio, 2007).

Senyawa flavonoid pada ekstrak kulit bawang merah dapat dimanfaatkan untuk mengurangi penyakit infeksi, terutama infeksi pada kulit atau dermatosis. Penyakit dermatosis sebagian besar disebabkan oleh bakteri Staphylococcus aureus. Menurut Dewi dkk (2010) diperoleh data bahwa $S$. aureus merupakan bakteri terbanyak penyebab penyakit dermatosi yaitu sebesar 40\%, diikuti Staphylococcus koagulase negatif (36,8\%), Enterobacter aerogenes (10,5\%), Streptococcus viridans $(5,3 \%)$ dan Escherechia coli $(5,3 \%)$. Penyakit kulit merupakan peringkat ketiga dari sepuluh penyakit utama dengan $86 \%$ adalah dermatotis diantara 192.414 kasus penyakit kulit di beberapa Rumah Sakit Umum di Indonesia tahun 2011 (Kemenkes, 2011) (dalam Nuradilah Syarif, Andi Zulkifli dan Ansariadi 2013).

Pemanfaatan metabolit sekunder dari ekstrak kulit bawang merah sebagai antibakteri dipengaruhi oleh metode ekstraksi dan pelarut yang digunakan. Berbeda metode ekstraksi dan pelarut akan berpengaruh pada senyawa metabolit yang ditarik dalam ekstrak tersebut. Menurut Rahayu, dkk (2015) hasil fitokimia ekstrak kulit bawang merah dengan menggunakan metode maserasi diperoleh fraksi air mengandung flavonoid, polifenol, saponin, terpenoid dan alkaloid. Fraksi etil asetat mengandung flavonoid, polifenol dan alkaloid. Fraksi $n$-heksana mengandung saponin, steroid dan terpenoid. Senyawa flavonoid yang terkandung pada ekstrak kulit bawang merah fraksi etil asetat adalah golongan flavonol.

Pengujian ekstrak kulit bawang merah terhadap S.aureus dipengaruhi oleh jumlah kosentrasi ekstrak yang digunakan. Semakin besar konsentrasi ekstrak yang digunakan maka semakin lebar zona hambat yang terbentuk. Ekstrak kulit bawang merah hasil maserasi dengan 
pelarut etanol $86 \%$ dapat menghambat pertumbuhan S.aureus. Hasil pengujian diperoleh zona hambat $5 \%$ adalah $7.00 \mathrm{~mm}, 10 \%$ adalah $8.30 \mathrm{~mm}, 20 \%$ adalah $9.60 \mathrm{~mm}, 40 \%$ adalah $11.00 \mathrm{~mm}$, $60 \%$ adalah $12.33 \mathrm{~mm}$, dan $80 \%$ adalah $14.3 \mathrm{~mm}$ (Misna dan Diana, 2016).

Penelitian mengenai kulit bawang merah umumnya menggunakan metode ekstrasi dengan pemanasan (sokletasi) atau tanpa pemanasan (maserasi) atau yang sering disebut dengan metode secara konvensial. Metode ekstraksi modern dengan memanfaatkan radiasi gelombang mikro yang disebut dengan MAE (Microwave Assited Extraction) belum banyak dilakukan. Menurut Gharekhani (2012) metode MAE terbukti lebih efektif karena pemanasan pelarut secara cepat dan efisien dibandingkan metode ekstraksi secara konvensional. Oleh karena itu tujuan dari peneltian ini adalah untuk mengetahui senyawa fitokimia yang terdapat pada ekstrak kulit bawang merah hasil MAE serta menguji aktivitasnya terhadap S.aureus. Hasil yang diperoleh diharapkan mempunyai zona hambat yang lebih besar dibandingkan penelitian dengan menggunakan metode yang konvensional.

\section{METODE PENELITIAN}

\section{Alat dan Bahan}

Alat yang akan digunakan dalam penelitian ini antara lain timbangan analitik, oven, grinder, ayakan mesh 40, tanur, desikator, Vacuum epavorator, Moisture balance, Vacuumdryer, spektrofotometer, alat-alat gelas, corong pisah, alat Shaker, aluminium foil, penangas air, wadah dan stopwatch.

Bahan yang digunakan adalah kulit bawang merah, kloroform, aquadest, asam sulfat, serbuk Magnesium, amonia, pereaksi Dragendorff, pereaksi Mayer, pereaksi Wagner, asam klorida, amil alkohol, besi (III) Klorida, asam asetat anhidrat.

\section{Jalannya Penelitian}

\section{A. Pengumpulan Bahan}

Kulit bawang merah yang digunakan dalam penelitian ini diperoleh dari petani bawang merah Sumenep, Madura dan Jawa Timur. Determinasi tanaman dilakukan di Pusat Konservasi Tumbuhan Kebun Raya Bogor, Lembaga Ilmu Pengetahuan Indonesia (LIPI). Pengeringan dilakukan dengan cara diangin-anginkan, tidak langsung terkena cahaya matahari. Simplisia kering disortasi, diblender sampai halus mejadi serbuk, dan diayak dengan ayakan mesh 40. Simplisia kering dilakukan penetapan kadar air dan kadar abu.

\section{B. Pembuatan Ekstrak dengan Metode MAE}

Sebanyak 50 g serbuk kulit bawang merah dimasukkan ke dalam erlenmeyer dan ditambahkan air sebanyak $500 \mathrm{ml}$ (1:10) kemudian dimasukkan ke dalam microwave yang berdaya 700 watt selama 4 menit 30 detik. Larutan diradiasi dalam microwave secara berkala (radiasi 30 detik dan 2 menit dimatikan) untuk menjaga suhu tidak naik $80^{\circ} \mathrm{C}$. Hasil rendemen ekstraknya kemudian dihitung, Hasil ekstraksi didiamkan sampai suhu kamar, disaring dan filtratnya diuapkan dengan penguap vakum hingga menjadi ekstrak. 


\section{Uji Fitokimia Flavonoid}

Sebanyak $2 \mathrm{~g}$ serbuk kulit bawang merah ditambah dengan $5 \mathrm{ml}$ air, lalu dipanaskan selama lima menit di dalam tabung reaksi. Selanjutnya ditambah beberapa tetes $\mathrm{HCl}$ pekat. Kemudian ditambahkan $0,2 \mathrm{~g}$ bubuk $\mathrm{Zn}$. Hasil positif ditunjukkan dengan timbulnya warna merah tua (magenta) dalam waktu 3 menit.

\section{Saponin}

Sebanyak $100 \mathrm{mg}$ serbuk kulit bawang merah dimasukkan ke dalam tabung reaksi, ditambah $10 \mathrm{ml}$ air suling sehingga seluruh cuplikan terendam, dididihkan selama 2-3 menit, dan selanjutnya didinginkan, kemudian dikocok kuat-kuat selama 30 menit, letakkan tabung dalam posisi tegak selama 30 menit, hasil positif ditunjukkan dengan terbentuknya buih yang stabil.

\section{Uji Tanin}

Sebanyak 2 g serbuk kulit bawang merah ditambah air sampai terendam semuanya. sebanyak $1 \mathrm{ml}$ larutan dipindahkan kedalam tabung reaksi dan ditambahkan 2-3 tetes larutan $\mathrm{FeCl}_{3}$ 1\%. Hasil positif ditunjukkan dengan terbentuknya warna hitam kebiruan atau hijau.

\section{Pembuatan Suspensi mikroba}

Bakteri yang digunakan dalam penelitian ini adalah $S$. aureus. Bakteri yang telah diremajakan selama 2 hari diambil menggunakan jarum ose kemudian masukkan kedalam tabung reaksi berisi $\mathrm{NaCl}$ fisiologis steril. Bakteri yang digunakan adalah kepadatan $10^{6} / \mathrm{ml}$ sebanyak 1 $\mathrm{ml}$ dengan metode pour plate (Hadioetomo, 1993).

\section{E. Pengujian Antimikroba}

Pengujian ekstrak terhadap $S$. aureus dilakukan dengan metode difusi kertas cakram. Kertas cakram yang digunakan berisi ekstrak berkisar 0,2 $\mu$ l dengan diameter $6 \mathrm{~mm}$. Diameter zona bening/hambat yang terbentuk diukur dengan menggunakan jangka sorong. Kosentrasi ekstrak yang digunakan adalah 5, 10, 15, 20 dan $25 \%$ b/v. Medium yang digunakan adana nutrient agar (NA). Medium NA dan suspensi mikroba dimasukkan secara bersamaan dan ditunggu hingga memadat. Masing-masing kertas cakram yang telah berisi ekstrak dan kontrol dimasukan ke dalam medium dan diinkubasi selama 24 jam pada suhu $37^{\circ} \mathrm{C}$. Kontrol + yang digunakan adalah Amoxilin 100 ppm dan kontrol - adalah DMSO.

\section{Analisis Data}

Antibakteri ditentukan dengan mengukur zona bening (tidak ditumbuhi bakteri) yang terdapat pada media (Hadioetomo, 1993). Posisi pengujian ekstrak dapat dilihat pada Gambar 4.

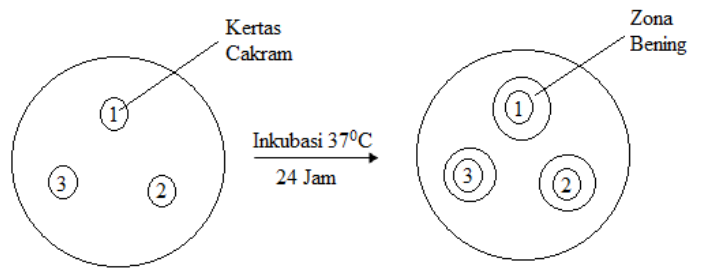

Gambar 4. Posisi Pengujian dengan metode Difusi Cakram (Kumalasari, 2012)

Keterangan :

$1=$ ekstrak kulit bawang merah;

$2=$ kontrol positif (antibiotik) ;

$3=$ kontrol negative 


\section{HASIL DAN PEMBAHASAN}

Berdasarkan uji fitokimia secara kualitatif, maka ekstrak kulit bawang merah memiliki senyawa flavonoid, saponin dan tanin. Hal tersebut ditunjukkan dengan terbentuknya warna magenta/merah pada uji flavonoid. Estrak terdapat buih menunjukkan adanya saponin setelah dilakukan pengocokan. Hasil positif senyawa tanin ditunjukan dengan terbentuknya warna hijau pada ekstrak. Hasil fitokimia tersebut sesuai dengan penelitian Misna dan Diana (2016) bahwa ekstrak kulit bawang merah dengan metode maserasi dan pelarut etanol $96 \%$ terdapat senyawa flavonoid dan tanin.

Hasil pengujian antibakteri ekstrak kulit bawang merah dengan metode MAE menunjukkan bahwa kosentrasi 5,10, 15, 20 dan 25\% mempunyai zona bening/hambat yaitu 14; 15,5; 16; 19; 19,5 mm (Tabel I).

Tabel I. Diameter zona hambat ekstrak kulit bawang merah dengan metode MAE terhadap $S$. aureus

\begin{tabular}{lccc}
\hline No & Kosentrasi (b/v) & $\begin{array}{c}\text { Rata-Rata } \\
(\mathbf{m m})\end{array}$ & Keterangan \\
\hline 1 & $5 \%$ & 14 & Kuat \\
\hline 2 & $10 \%$ & 15,5 & Kuat \\
\hline 3 & $15 \%$ & 16 & Kuat \\
\hline 4 & $20 \%$ & 19 & Kuat \\
\hline 5 & $25 \%$ & 19,5 & Kuat \\
\hline 6 & $\mathrm{~K}+($ Amoxilin $100 \mathrm{ppm})$ & 35 & Kuat \\
\hline 7 & $\mathrm{~K}-($ DMSO) & 0 & Lemah \\
\hline
\end{tabular}

Ket: 0-3 mm : lemah; 3-6 mm: sedang; > 6 mm: kuat (Pan et al., 2009)

Hasil penelitian tersebut berbeda dengan hasil penelitian Misna dan Diana (2016), dimana pada kosentrasi yang sama yaitu 5, 10 dan $20 \%$ mempunyai zona hambat 7; 8,3 dan 9,6 mm dengan metode maserasi pelarut etanol 96\%. Hasil tersebut menunjukan bahwa metode MAE lebih efektif dan menghasilkan zona hambat lebih besar dibandingkan dengan metode maserasi. Menurut Gharekhani (2012) metode MAE terbukti lebih efektif karena pemanasan pelarut secara cepat dan efisien dibandingkan metode ekstraksi secara konvensional.

Hasil penelitian ekstrak kulit bawang merah dengan metode MAE terhadap bakteri S.aureus pada kosentrasi 5, 10, 15, 20, dan $25 \%$ b/v menunjukkan bahwa semakin besar kosentrasinya maka semakin besar zona hambat yang dihasilkan (Gambar 1). Kosentrasi hambat minimum dari ekstrak kulit bawang merah berada pada kosentrasi $5 \% \mathrm{~b} / \mathrm{v}$. Hal ini ditunjukkan dengan telah terbentuknya zona hambat pada kosentrasi minimum $(5 \% \mathrm{~b} / \mathrm{v})$ dengan diameter 14 mm. Hasil penelitian Ibriani (2012) menyebutkan bahwa ekstrak umbi bawang merah yang dilarutkan dengan beberapa pelarut memberikan hasil yang berbeda setelah diujikan dengan S.aureus. Ekstrak kental umbi bawang merah dengan konsentrasi ekstrak 10\% b/v menunjukan hasil kurang menghambat pertumbuhan S.aureus, sedangkan ekstrak dengan fraksi larut n-heksan dan fraksi tidak larut n-heksan menunjukan hasil yang lebih buruk dari ekstrak kental yaitu tidak terbentuk zona hambat. Hal ini menunjukkan bahwa metode MAE lebih efektif dalam menarik 
senyawa metabolit yang terdapat pada ekstrak, sehingga kosentrasi hambat minimum yang dihasilkan lebih kecil.

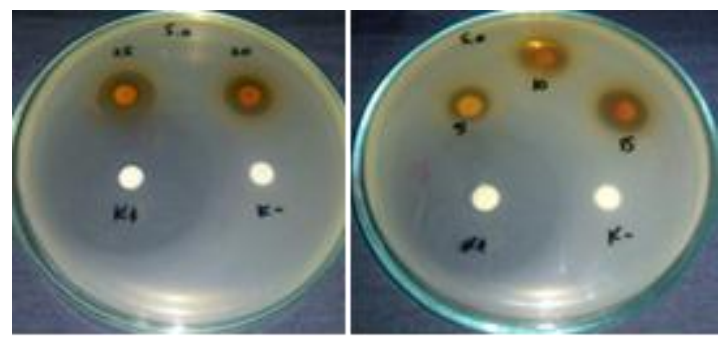

\section{Gambar 1. Zona hambat ekstrak kulit bawang merah terhadap Staphylococcus aureus \\ Keterangan :}

$5 \quad$ : konsentrasi ekstrak $5 \%$

10 : konsentrasi ekstrak $10 \%$

15 : konsentrasi ekstrak $15 \%$

20 : konsentrasi ekstrak $20 \%$

25 : konsentrasi ekstrak $25 \%$

$\mathrm{K}(-) \quad$ : kontrol negatif

$\mathrm{K}(+) \quad$ : kontrol positif (antibiotik)

Besar kecilnya zona hambat yang terbentuk pada berbagai ekstrak dipengaruhi oleh metode ekstraksi serta pelarut yang digunakan. Zona hambat yang terbentuk dipengaruhi oleh senyawa yang bersifat sebagai antibakteri pada ekstrak tersebut. Penggunaan metode ekstraksi dan pelarut yang tepat akan mempengaruhi luas sempitnya zona hambat (antibakteri) yang terbentuk (Lapornik et al., 2005). Selain kosentrasi, adanya zona hambat yang terbentuk, dikarenakan ekstrak kulit bawang merah mempunyai senyawa metabolit sekunder yang bersifat sebagai antibakteri. Senyawa tersebut diantaranya adalah flavonoid, saponin dan tanin (Tabel II).

Tabel II. Uji fitokimia ekstrak kulit bawang merah metode secara kualitatif

\begin{tabular}{llllc}
\hline No & Zat aktif & Hasil teori & Hasil uji & Keterangan \\
\hline 1 & Flavonoid & Berwarna magenta/merah & $\begin{array}{l}\text { Berwarna } \\
\text { magenta/merah }\end{array}$ & + \\
\hline 2 & Saponin & Terbentuknya buih & Terbentuknya buih & + \\
\hline 3 & Tanin & Berwarna hijau & Berwarna hijau & + \\
\hline
\end{tabular}

Menurut Kmar \& Pandey, (2013) Flavonoid merupakan senyawa fenolik yang terhidroksilasi dan disintesis oleh tanaman sebagai respon terhadap infeksi mikroba. Sifat kimia flavonoid tergantung pada struktur, tingkat hidroksilasi, substitusi dan konjugasi, serta derajat polimerisasi. Senyawa flavonoid suatu kelompok senyawa fenol yang terbesar ditemukan di alam. Flavon salah satu jenis flavonoid yang terbesar jumlahnya dan sering ditemukan di alam. Flavonoid yang bersifat polar merupakan senyawa yang larut dalam air, dalam jaringan tumbuhan sifat kelarutan dan reaksi warna meliputi antosianin, proantosianin, flavonol, flavon, glikoflavon, biflavonol, kalkon dan auron, flavonon dan isoflavon. Penggunaan pelarut air pada metode MAE sesuai dengan senyawa yang akan ditarik yaitu senyawa yang bersifat polar. 
Mekanisme kerja flavonoid menghambat fungsi membran sel adalah membentuk senyawa kompleks dengan protein ekstraseluler dan terlarut sehingga dapat merusak membran sel bakteri dan diikuti dengan keluarnya senyawa intraseluler (Nuria dkk 2009). Penelitian lain menyatakan mekanisme flavonoid menghambat fungsi membran sel dengan cara mengganggu permebealitas membran sel dan menghambat ikatan enzim seperti ATPase dan phospholipase (Li dan Liu 2003). Flavonoid dapat menghambat metabolisme energi dengan cara menghambat penggunaan oksigen oleh bakteri. Flavonoid menghambat pada sitokrom $\mathrm{C}$ reduktase sehingga pembentukan metabolisme terhambat. Energi dibutuhkan bakteri untuk biosintesis makromolekul (Cushnie et al 2005).

Mekanisme kerja saponin sebagai antibakteri yaitu dapat menyebabkan kebocoran protein dan enzim dari dalam sel (Madduluri, 2013). Saponin dapat menjadi anti bakteri karena zat aktif permukaannya mirip detergen, akibatnya saponin akan menurunkan tegangan permukaan dinding sel bakteri dan merusak permebialitas membran. Rusaknya membran sel ini sangat mengganggu kelangsungan hidup bakteri (Harborne, 2006). Saponin berdifusi melalui membran luar dan dinding sel yang rentan kemudian mengikat membran sitoplasma sehingga mengganggu dan mengurangi kestabilan membran sel. Hal ini menyebabkan sitoplasma bocor keluar dari sel yang mengakibatkan kematian sel. Agen antimikroba yang mengganggu membran sitoplasma bersifat bakterisida.

Mekanisme kerja antibakteri tanin mempunyai daya antibakteri dengan cara memprepitasi protein. Efek antibakteri tanin melalui reaksi dengan membran sel, inaktivasi enzim dan inaktivasi fungsi materi genetik. Mekanisme kerja tanin sebagai antibakteri adalah menghambat enzim reverse transkriptase dan DNA topoisomerase sehingga sel bakteri tidak dapat terbentuk (Nuria, dkk 2009). Tanin memiliki aktivitas antibakteri yang berhubungan dengan kemampuannya untuk menginaktifkan adhesin sel mikroba, menginaktifkan enzim, dan menggangu transport protein pada lapisan dalam sel (Cowan, 1999).

\section{KESIMPULAN}

Ekstrak kulit bawang merah dengan metode Microwave Assisted Extraction (MAE) dapat menarik senyawa flavonoid, saponin dan tanin serta dapat menghambat bakteri S.aureus lebih baik dibandingkan dengan metode maserasi.

\section{UCAPAN TERIMAKASIH}

Penulis berterima kasih kepada Kementerian Riset, Teknologi, dan Pendidikan Tinggi Republik Indonesia, Lembaga Penelitian dan Pengabdian Masyarakat Universitas Pakuan dan Program Studi Farmasi Fakultas Matematika dan Ilmu Pengetahuan Alam, Universitas Pakuan.

\section{DAFTAR PUSTAKA}

Akiyama, H. K. Fujii. O. Yamasaki., T. Oono. K. Iwatsuki. 2001. Antibacterial action of several tannin against Staphylococcus aureus. Journal of Antimicrobial Chemotherapy 48: 487 - 491.

Cavalieri, S.J., I.D. Rankin., R.J. Harbeck., R.S. Sautter., Y.S. McCarter., S.E. Sharp., J.H. Ortez., dan C.A. Spiegel. 2005. Manual of antimicrobial susceptibility testing. USA: American Society for Microbiology. 
Cowan, M.M. 1999. Plant products as antimicrobial agents. Clinical Microbiology Reviews 12: $564-582$.

Cushnie, T.P.Tim. Lamb, Andrew J. 2005. Amtimicrobial activity of flavonoids. International Journal of Antimicrobial Agents 26: 343-356.

Dewi, Rosalina, Sunarko, Martodihardjo, M. Y. Listiawan. 2010. Staphylococcus aureus sebagai penyebab tersering infeksi sekunder pada semua erosi kulit Dermatosis Vesikobulosa . Berkala Ilmu Kesehatan Kulit \& Kelamin 22.(2): 102-108.

Gharekhani, M., Ghorbani M., dan Rasoulnejad N., 2012. Microwave assisted extraction of phenolic and flavonoid compounds from eucalyptus camaldulensis dehn leaves as compared with ultrasound-assisted ectraction. Lat.Am.appl.res. 42 (3).

Hadioetomo, R. S. 1993. Mikrobiologi Dasar Dalam Dalam Praktek. Penerbit PT Gramedia Pustaka Utama. Jakarta

Harborne, J.B. 2006. Metode Fitokimia Edisi ke-2. Bandung: ITB.

Lapornik, B., M. Prosek and A.K. Wondra. 2005. Comparison of extracts prepared from plant byproducts using different solvents and extraction time. Journal of Food Engineering 71 (2): 214-222.

Li, H. Wang, Z. Liu, Y. 2003. Review in the studies on tannins activity of cancer prevention and anticancer. Zhong-Yao-Cai. 26(6): 444-448.

Madduluri, Suresh. Rao, K. Babu. Sitaram, B. 2013. In vitro evaluation of antibacterial activity of five indegenous plants extract against five bacterial pathogens of human. International Journal of Pharmacy and Pharmaceutical Sciences 5(4): 679-684.

Nuria, Maulita Cut, Faizaitun, Arvin, Sumantri. 2009. Uji aktivitas antibakteri ekstrak etanol daun Jarak Pagar (Jatropha Curcas L) terhadap bakteri Staphylococcus aureus Atcc 25923, Escherichia Coli Atcc 25922, Salmonella typhi Atcc 1408. Mediagro 5(2):26-37.

Misna dan Diana K. 2016. Aktivitas antibakteri ekstrak kulit bawang merah (Allium cepa L) terhadap bakteri Staphylococcus Aureus. Galenika Journal of Pharmacy 2(2): 138-144.

Palczar, J.M dan Chan, E.C.S. 1988. Dasar-dasar Mikrobiologi 2. Jakarta: Penerbit UI Press.

Pan, X., Chen, F., Wu, T., Tang, H., and Zhao, Z. 2009. The acid, bile tolerance and antimicrobial property of Lactobacillus acidophilus. J. Food Control 20: 598-602.

Rahayu, Siti; N. Kurniasih, Dan V Amalia. 2015. Ekstraksi dan identifikasi senyawa flavonoid dari limbah kulit bawang merah sebagai antioksidan alami. Al Kimiya 2 (1): 1-8 
Sari, F.P. dan S. M. Sari. Ekstraksi zat aktif antimikroba dari tanaman yodium (Jatropha multifida Linn) sebgai bahan baku alternatif antibiotik alami. Semarang: Fakultas Teknik Universitas Diponegoro. 2011.

Soebagio, B., Rusdiana, T. dan Khairudin. 2007. Pembuatan Gel dengan Aqupec HV-505 dari Ekstrak Umbi Bawang Merah (Allium cepa, L.) sebagai Antioksidan. Fakultas Farmasi, Universitas Padjadjaran. Bandung 